\title{
Special Education Funding in Nova Scotia, Canada: A Scoping Review of the Literature
}

\author{
David C. Young, Daniel B. Robinson \\ St. Francis Xavier University, Canada
}

\begin{abstract}
This article reports on the findings from a scoping literature review regarding the issue of special education funding. In addition to the academic literature, governmental/ministerial material was drawn from each of the provinces and territories. When relevant, international perspectives were embedded in the article. The discussion was organized thematically, with recommendations to the status quo offered.
\end{abstract}

\section{Introduction}

In a 2005 piece, Daniel notes that “...questions of cost-efficiency and value for money pose special dilemmas for special educational resources in times of tight budgeting and audits (p. 764). Although written more than a decade ago, and in reference to the province of Ontario, the basic premise raised is quite applicable to present-day Nova Scotia. As the province works towards putting its fiscal house in order, the "problem of the purse" is ever-present, as needs and/or demands seem to constantly outpace available resources. The ultimate result of this tension can be summed up as adequacy: how much is enough? [44]. Indeed, this is a vexing question, as the provision of services for children with exceptionalities is predicated on teachers and students alike having access to the resources they require. From specialized therapies, to the acquisition of both high- and low-tech assistive and/or adaptive technology, to salaries for educators and other professionals, including paraprofessionals, to the very classrooms themselves, each equates in some way to the notion of finances. As a 2017 study by the Organisation for Economic Co-operation and Development (OECD) puts it, "the level of public expenditure partly reflects the degree to which governments value education" ( $p$. 194). In Canada, there is a public perception that governments need to increase expenditures associated with education if our students are to receive a quality education.
This article will provide an overview of the literature surrounding the funding of special education. Although international perspectives will be offered when and where appropriate, the focus and scope will remain largely domestic. By drawing on examples from all provinces and territories, a pan-Canadian overview is possible, which will facilitate in both comparing and contrasting the arrangements found in each jurisdiction. However, it is important to note that although recommendations will be advanced in regards to the funding of special education in Nova Scotia post-2018, the temptation to critique in terms of right or wrong, or best and worst, has intentionally been avoided. There is no unequivocal "best" special education model, but rather, province and territories have each developed their own individual systems respective of their context and prevailing ideologies [45].

Before turning specifically to the issue of special education funding, a brief overview of the literature review itself will be presented.

\section{The Literature Review: Parameters and Specifics}

It is important to keep in mind that "the first step in research is to assess what is already known..." [19]. In terms of this particular review of the literature, a Research Assistant (RA) was employed to conduct an initial scan of the field to determine what sources were available. To employ a technical vocabulary, the RA engaged in what is often referred to as a scoping review, in which the effort was directed at documenting what was already known, all the while maintaining a critical stance. The RA was charged with conducting a thorough review of the available databases, and maintaining a search record. Although one might expect to uncover a wealth of sources dealing with educational finance/funding, much of the material was not particularly relevant to the topic addressed in this paper. 
In fact, more success was found in examining the various department/ministry web sites to ascertain the model of funding in the provinces and territories. However, it worth noting that although some of these web sites were accessible and it was quite simple to locate the source material, others required more substantive searching. Regardless, when combining the material - both print and electronic - in totality, a picture does emerge of how special education is funded in Canada. One is also able to draw some conclusions as to how the system might be restructured to ensure an efficient delivery of services.

Once the scoping activity was concluded, the findings were written via a thematic analysis. That is, material was chunked according to emergent patterns.

\section{Special Education: Some Initial Observations}

The issue of funding special education has been a recurring theme in educational and policy circles for many years. The 1994 United Nations Educational, Scientific and Cultural Organization's (UNESCO) Salamanca Statement, which was based on input from 92 countries and 25 international organizations, called on governments, among other things, to "give the highest policy and budgetary priority to improve their education systems to enable them to include all children regardless of individual differences or difficulties ( $p$. ix). In the Nova Scotia context, the 2014 Report of the Minister's Panel on Education indicated “... that current levels of funding and other resources are hindering the educational experience of all students in the system because the resources are not keeping pace with the growing needs of students" (p. 40). The Report further notes that increased funding can't nor should it be the sole means by which to address this issue. Regardless of whether or not funding in terms of real dollar amounts is increased, steps must be taken to improve the overall educational experience for students and educators alike.

In thinking about the inclusion of children with exceptionalities in regular classroom settings, it can be argued that most teachers are generally supportive of this initiative, at least from a purely philosophical standpoint [47]. This can be seen as a positive, since as Ryan [40] notes, "inclusion's alter ego is exclusion." Certainly, exclusion has extremely negative connotations, and is a practice that should find no place in our schools [17]. Although teachers may indicate a philosophical support for inclusion, it does appear that there remain stumbling blocks when examining the practical implementation of inclusion. For some teachers, there is a general feeling that they lack the skills, knowledge, and attributes required to teach students with exceptionalities [7]; [18]. An additional issue frequently raised by teachers is in regards to a lack of supports. The nature of special education often requires "...that supports be brought to the classroom to the child, not that the child be removed to the supports" [45]. In a Nova Scotia study that involved 725 teachers, it was found that 77 per cent of respondents felt they did not possess adequate resources [9]. Related to this issue of lacking support is the view that funding, and who should provide it, is a major impediment.

\section{Special Education as a System}

The genesis for the Canadian public education system is based on the principles of public funding and provincial control, and can be traced back to Confederation. Section 93 of the 1867 British North America Act (later known as the Constitution Act, 1982) established the legitimacy for public education in this country. According to section 93, the "...the Legislature may exclusively makes Laws in relation to Education," and as a result, education became an unequivocal and exclusive provincial responsibility [3]. It is also important to recognize that while constitutional power in the territories was initially vested in the federal government, most of this power has since been delegated to the governments of the Yukon and Northwest Territories, as well as Nunavut [34]. Therefore, in the one hundred and fifty years that have elapsed since Confederation, "...education is and continues to remain a responsibility of the provincial and territorial governments" [46].

Across Canada, special education does tend to vary between locales, and is largely driven by provincial/territorial policy. As such, there are some common elements shared among the various jurisdictions, but difference remains as a constituent feature of the landscape [4]. This difference dimension can even be seen at the local level, where it is not uncommon to see different approaches to special education at schools within the same board. As Winzer [45] points out, "...it is probably more apt to talk about inclusions rather than a single inclusion."

In terms of a snapshot, Table 1 provides an outline of provincial and territorial policy in Canada (see Table $1)$.

\section{The Economic Aspects of Education}

Even a cursory examination of the funding of the Canadian public education system appears to point to a theme of centralization at the ministerial/department level. This stands in stark contrast to the historical record in which revenue to support education was generated largely through fees, local property taxes, and 
Table 1. Snapshot of Canadian provincial/territorial inclusion policies

\begin{tabular}{|c|c|}
\hline Province & Policy \\
\hline British Columbia & $\begin{array}{l}\text { "British Columbia promotes an inclusive education system in which students with } \\
\text { special needs are fully participating members of a community of learners. Inclusion } \\
\text { describes the principle that all students are entitled to equitable access to learning, } \\
\text { achievement and the pursuit of excellence in all aspects of their educational programs. } \\
\text { The practice of inclusion is not necessarily synonymous with full integration in regular } \\
\text { classrooms, and goes beyond placement to include meaningful participation and the } \\
\text { promotion of interaction with others" (British Columbia Ministry of Education, 2016, } \\
\text { p. 2). }\end{array}$ \\
\hline Alberta & $\begin{array}{l}\text { "Special education refers to the education of students with mild, moderate, or severe } \\
\text { disabilities and those who are gifted and talented. It is founded on the belief that all } \\
\text { children can learn and reach their full potential given opportunity, effective teaching } \\
\text { and appropriate resources. Instruction, rather than setting, is the key to success and } \\
\text { decisions related to the placement of students are best made on an individual basis in a } \\
\text { manner that maximizes their opportunity to participate fully in the experience of } \\
\text { schooling" (Alberta Education, 2004, p. 1). }\end{array}$ \\
\hline Saskatchewan & $\begin{array}{l}\text { "In Saskatchewan, we are guided by the philosophy and principles of a needs-based } \\
\text { model to provide supports for students. This model focuses on the strengths, abilities } \\
\text { and needs of each individual student. } \\
\text { Students are supported in inclusive settings by a collaborative team that includes their } \\
\text { parents, education professionals and other individuals who can help the student reach } \\
\text { his or her goals. } \\
\text { Students whose needs require a significant level of support may benefit from an } \\
\text { Inclusion and Intervention Plan" (Government of Saskatchewan, n.d.). }\end{array}$ \\
\hline Manitoba & $\begin{array}{l}\text { "[The] goal is to ensure that children with special needs benefit from an educational } \\
\text { experience that includes quality learning opportunities with expectations that consider } \\
\text { each child's individual needs" (Manitoba Education, Citizenship and Youth, 2004, p. } \\
\text { 1). }\end{array}$ \\
\hline Ontario & $\begin{array}{l}\text { "The ministry recognizes that every student is unique and that each must have } \\
\text { opportunities to achieve success according to his or her own interests, abilities, and } \\
\text { goals. It also recognizes that among children and youth who are at risk of not } \\
\text { succeeding are those with special education needs" (Ontario Ministry of Education, } \\
2017 \text {, p. 2). }\end{array}$ \\
\hline Québec & $\begin{array}{l}\text { The key is "...creating an environment that is conducive to learning and in detecting } \\
\text { difficulties and intervening as soon as they appear.... The policy states that the } \\
\text { organization of educational services be student-centred and that it be based on an } \\
\text { individualized evaluation of their needs and abilities" (Gouvernement du Québec, } \\
2007, \text { p. 2). }\end{array}$ \\
\hline New Brunswick & $\begin{array}{l}\text { Inclusive through "...the pairing of philosophy and pedagogical practices that allows } \\
\text { each student to feel respected, confident and safe so he or she can participate with } \\
\text { peers in the common learning environment and learn and develop to his or her full } \\
\text { potential. It is based on a system of values and beliefs centered on the best interest of } \\
\text { the student, which promotes social cohesion, belonging, active participation in } \\
\text { learning, a complete school experience, and positive interactions with peers and others } \\
\text { in the school community" (New Brunswick Department of Education and Early } \\
\text { Childhood Development, 2013). }\end{array}$ \\
\hline Nova Scotia & $\begin{array}{l}\text { "The goal of inclusive schooling is to facilitate the membership, participation and } \\
\text { learning of all students in school programs and activities. The support services that are } \\
\text { designed to meet students' diverse educational needs should be co-ordinated within the } \\
\text { neighbourhood school and to the extent possible, within grade level/subject area } \\
\text { classrooms" (Nova Scotia Department of Education, 2008, p. 5). }\end{array}$ \\
\hline
\end{tabular}




\begin{tabular}{|l|l|}
\hline Prince Edward Island & $\begin{array}{l}\text { "The purpose of the Prince Edward Island public education system is to provide for the } \\
\text { development of children so that each child may take a meaningful place in society. }\end{array}$ \\
$\begin{array}{l}\text { For some students, individual planning may result in modifications to the provincially } \\
\text { authorized and prescribed curriculum to meet that individual student's special } \\
\text { education needs" (Prince Edward Island Department of Education, Early Learning and } \\
\text { Culture, 2015, p. 20 \& 25). }\end{array}$ \\
\hline $\begin{array}{l}\text { Newfoundland and } \\
\text { Labrador }\end{array}$ & $\begin{array}{l}\text { "While the concept of inclusive education is typically associated with including special } \\
\text { needs children in the classroom environment, this is not an accurate reflection of the } \\
\text { Department of Education and Early Childhood Development's vision. In reality, the } \\
\text { goal of inclusive education is that students are included in ALL aspects of the learning } \\
\text { environment regardless of any facet of diversity. Such inclusive education involves } \\
\text { much more than just student placement. It embraces all students and involves } \\
\text { everything that happens within the school community: culture, policies, and practices" } \\
\text { (Government of Newfoundland and Labrador, n.d.). }\end{array}$ \\
\hline Yukon Territory & $\begin{array}{l}\text { "The vision for inclusive schools in the Yukon is that every student feels accepted, } \\
\text { valued and safe in school and students' strengths and challenges are central to all } \\
\text { decisions" (Yukon Department of Education, 2015, p. B-2). }\end{array}$ \\
\hline Northwest Territories & $\begin{array}{l}\text { Inclusive schooling as a means "to ensure access to quality education for all students } \\
\text { by effectively meeting their diverse needs in a way that is responsive, accepting, } \\
\text { respectful and supportive" (Government of Northwest Territories, 2017, p. 2). }\end{array}$ \\
\hline Nunavut & $\begin{array}{l}\text { "In order to provide appropriate environments for continuous and inclusive learning, } \\
\text { the school system must build an approach to inclusion that promotes and enhances } \\
\text { learning for everyone - students, parents, educators, and community members" } \\
\text { (Nunavut Department of Education, 2008, p. 18). }\end{array}$ \\
\hline
\end{tabular}

in some instances, support from various religious denominations. However, in the current context, only Saskatchewan, Manitoba, and Québec continue to have significant local property taxes. More typical is the arrangement whereby provincial and territorial governments account for nearly all of the monies allocated to school boards. This is the case in British Columbia, Alberta, Ontario, New Brunswick, Prince Edward Island, Newfoundland and Labrador, Nunavut and the Yukon [48]. Under this type of centralized funding regime, the provincial or territorial government allocates to boards financial support as drawn from the general revenue of the province or territory. In a very simplistic sense, most of this funding is provided to the province or territory via: (1) a block grant; (2) categorical funding (sometimes referred to as demanddriven or an input model); and (3) equalization funding. A block grant accounts for the largest financial transfer, and is normally based on the number of students enrolled in a school board. Categorical funding involves money earmarked for particular programs, such as special education. And last, equalization funding is a mechanism to equalize a board's fiscal capacity to deliver programs and services. In essence, it is a means to ensure a level playing field [48].

In the contemporary context, public education, with the exception of health care, continues to be the most costly public expenditure. In fact, in looking at real dollar figures, it costs some $\$ 50$ billion per year to fund the 15,500 public and separate schools in Canada [34]. According to estimates, staff salaries (79\%), especially those of teachers, represents the largest proportion of spending in the area of elementary and secondary public education (Statistics Canada, 2017).

Also in terms of funding, we need to recognize that in addition to provincial and territorial expenditures, the federal government also contributes monies to public education through transfer payments. In fact, in 2014 Canada allocated $6.0 \%$ of its gross domestic product (GDP) to educational institutions, which is more than the average of $5.2 \%$ among comparator OECD countries (Statistics Canada, 2017). In looking at real dollar amounts, the OECD estimates that at the primary level, Canada as a whole spends approximately $\$ 9256.00$ US dollars per student. At the secondary level, real dollar spending is $\$ 12,780$ US (OECD, n.d.). In terms of Nova Scotia specifically, per student funding for public schools was found to be $\$ 13,179$ [21].

If we look at total spending in government schools, a picture does emerge that seems to point a picture of increased expenditures. The chart below, drawn from the work of MacLeod and Emes [21] shows both Canadian and national trends in spending (see Table 2). This data is telling in that if we begin to examine provinces, with the exception of British Columbia, Nova Scotia has the lowest percent change in terms of dollars spent between 2005/2006 and 2014/2015. And when comparing Nova Scotia with some of the biggest 
spenders, the discrepancy in the percent change is dramatic. In fact, seven provinces had an increase in spending of greater than $35 \%$. This differential in terms of spending undoubtedly has a tangible and real impact on student learning.

In looking specifically at special education funding, most but not all provinces employ a block grant funding model. However, there are some unique variations when comparing provinces and territories.

The following derived from Towle [42] outlines some of the unique special education funding models in Canada (see Table 3).

\section{Alternatives to the Status Quo}

In thinking about special education funding, there is little dispute that to provide an appropriate education for children with exceptionalities, adequate financial resources must be in place. In fact, in a study that examined seventeen European countries, it was found that funding is one of the most important factors in creating an inclusive education system [23]. Certainly, school boards must be given the means whereby they can deliver a quality and appropriate education to all children under their charge. As Table 2 has pointed out, Nova Scotia's spending - from a percentage change - in the area of public education has been among the lowest in the country, save British Columbia. The easiest and most straight-forward recommendation might be to simply advocate for increased government expenditures. And pragmatically, this makes sense, especially given the fact that as an example, a 2015 People for Education survey found that school boards in Ontario pay significantly more for special education services than they receive from the province (p. 19). To address this shortfall, Ontario announced in April of 2017 that they planned to invest $\$ 23.8$ billion in education during the 2017-2018 school year. More specifically, much of this money was to be dedicated to special education services and reducing class sizes [12]. The approach taken by Ontario seems to reflect the fact that special education and classroom size have an inherent link. As costs associated with public education have continued to rise, the number of children with an identified exceptionality in classrooms has also increased. Data from a Canadian Teachers Federation survey of some 3800 teachers across the country points out that $16.3 \%$ of students in the surveyed classrooms had an identified exceptionality [11]. This is compounded by the fact that in some cases, classroom size has increased. "Class size matters, but so does class composition - in other words, when we talk about class size, we also need to be thinking about the degree of student diversity in those classes. In order to enhance quality and equity in our public schools, they need to be addressed together" (2012, n.p.). From an economies of scale standpoint, the investment by Ontario in pure dollars is not readily transferable to Nova Scotia, but the point to be made is that increased expenditures could result in positive net gains for all those involved in public education.

It is equally important that in addition to the funding allocated to boards being adequate, it needs to be predictable in that boards can depend on stable funding across multiple years. Further, funding needs to be "identification neutral" in that it should not be based only on those children identified as exceptional [35]. Besides each of these factors, funding needs to be spent wisely.

For example, some studies show only about $62 \%$ of special education dollars are being used for direct special education instructional services. For students with mild disabilities in resource room programs, an average $22 \%$ of all funds for special education services were spent on assessment and $15 \%$ on special education program administration. Questions are being raised about whether some of these dollars might be better spent on direct services [36].

In a somewhat similar vein, Murgatroyd and Couture [26] describe the "bounty phenomenon" in which boards, when faced with ever-increasing student needs, begin a referral process in an attempt to secure additional funding. This in turn results in school psychologists spending their time on completing assessments, when their time could actually be better spent working with students in schools. In this regard, it may be appropriate to also consider the issue of reallocation of resources. To give one example, the province of Nova Scotia currently employs approximately 1700 teacher/educational assistants. If we estimate conservatively a salary of $\$ 30,000$ per year, this equates to $\$ 51,000,000$ in spending.

If even a portion of this money could be diverted, it would allow for such things as the hiring of more special education teachers and other frontline professionals. Further, it might also facilitate the hiring of additional general education teachers, which could have a positive impact on classroom size.

As policy-makers grapple with special education funding, it is perhaps vitally important to step back for just a moment, and think about the concept of equity, and more importantly, horizontal and vertical equity [48]. Horizontal equity argues that all individuals should be treated in a like fashion, and as such, per-pupil funding should be very similar in all schools and in all boards. 
Table 2. Education spending in government schools

\begin{tabular}{|l|l|l|l|l|}
\hline & $\begin{array}{l}2005 / 20006 \\
(\$ \text { millions })\end{array}$ & $2014 / 2015$ (\$ millions) & $\begin{array}{l}\text { Nominal Change } \begin{array}{l}\text { \$ } \\
\text { millions })\end{array} \\
\text { Change }\end{array}$ \\
\hline Canada & 46,444 & 63,939 & 17,494 & 37.7 \\
\hline British Columbia & 5,508 & 6,200 & 692 & 12.6 \\
\hline Alberta & 5,171 & 8,257 & 3,086 & 59.7 \\
\hline Manitoba & 1,819 & 2,606 & 787 & 43.2 \\
\hline Saskatchewan & 1,592 & 2,628 & 1,036 & 65.0 \\
\hline Ontario & 19,470 & 26,596 & 7,125 & 36.6 \\
\hline Québec & 9,393 & 13,116 & 3,723 & 39.6 \\
\hline New Brunswick & 1,066 & 1,370 & 305 & 28.6 \\
\hline Nova Scotia & 1,276 & 1,573 & 298 & 23.3 \\
\hline Prince Edward Island & 168 & 251 & 236 & 36.4 \\
\hline $\begin{array}{l}\text { Newfoundland } \\
\text { Labrador }\end{array}$ & 649 & 885 & & \\
\hline
\end{tabular}

Table 3. Special education funding models in Canada

\begin{tabular}{|l|l|}
\hline Province & Funding Arrangement \\
\hline British Columbia & $\begin{array}{l}\text { Funding for each full-time student (79\% of budget). Unique funding for special needs } \\
\text { constitutes 12\% of the education budget. Level 1 funding (multiple, \$36,000 FTE); Level 2 } \\
\text { funding (intellectual, \$18,300 FYTE); and Level 3 funding (behavior/mental illness, \$9200 } \\
\text { FTE). }\end{array}$ \\
\hline Alberta & $\begin{array}{l}\text { Formula: Amount of supports and services allocation + differential modifiers allocation + } \\
\text { program equity support + additional per-student allocation. Alberta also boasts an equity } \\
\text { opportunity grant for rural schools, and a regional collaborative services delivery grant that } \\
\text { supports families with complex needs. }\end{array}$ \\
\hline Saskatchewan & $\begin{array}{l}\text { A Support for Learning (SFL) grant provides funding for salaries of teachers and } \\
\text { professionals who provide services to ensure all students have access to inclusive education. } \\
\text { The SFL grant constitutes 15.4\% of all provincial education funding. }\end{array}$ \\
\hline Manitoba & $\begin{array}{l}\text { Manitoba has a shared arrangement between Health and Education and family Services. In } \\
\text { addition to block grants, also has Level 2 (full-time EA most of the day) and Level 3 (all day } \\
\text { EA) funding in place. }\end{array}$ \\
\hline Ontario & $\begin{array}{l}\text { Ontario: Per-pupil funding exists, as well as Special Purpose Grants (based on diversity of } \\
\text { students enrolled). }\end{array}$ \\
\hline Québec & $\begin{array}{l}\text { Funding is distributed to school boards in an "equitable way." Funding is allocated to four } \\
\text { different programs: administration, educators at all levels, sports and leisure development } \\
\text { and retirement plans. }\end{array}$ \\
\hline
\end{tabular}




\begin{tabular}{|l|l|}
\hline New Brunswick & $\begin{array}{l}\text { A direct funding model is employed whereby special education funding is based on } \\
\text { enrollment. The funding is then allotted for salaries of resource teachers, teacher assistants, } \\
\text { supplies and equipment. }\end{array}$ \\
\hline Nova Scotia & $\begin{array}{l}\text { A special education formula-funding grant (targeted funding) is allotted to each school } \\
\text { board. A further Special Education Grant is also part of the funding mechanism. }\end{array}$ \\
\hline $\begin{array}{l}\text { Prince Edward } \\
\text { Island }\end{array}$ & $\begin{array}{l}\text { School boards are required to allocate staff and resources equally among schools. } \\
\text { Instructional staff for high-needs is allocated at an incidence rate of 7\% of enrolment (one } \\
\text { instructional position per board for every 14 students), while students with lower needs are } \\
\text { assigned one instructional position per board for every 500 students. }\end{array}$ \\
\hline $\begin{array}{l}\text { Newfoundland } \\
\text { and Labrador }\end{array}$ & $\begin{array}{l}\text { Funding is provided directly to school boards from the provincial General Revenue Fund. } \\
\text { Administration is also coordinated across four departments: Health and Community } \\
\text { Services, Education and Early Childhood Development, Human Resources and } \\
\text { Employment, and Justice. }\end{array}$ \\
\hline Yukon Territory & $\begin{array}{l}\text { Each board receives funding to meet its approved annual operations. As well, 1.5 } \\
\text { educational assistants are provided for every 261 students. }\end{array}$ \\
\hline $\begin{array}{l}\text { Northwest } \\
\text { Territories }\end{array}$ & $\begin{array}{l}\text { School funding is based on enrollment data to cover both annual operating and maintenance } \\
\text { costs. }\end{array}$ \\
\hline Nunavut & A block funding model is used in terms of allocation of resources. \\
\hline
\end{tabular}

Table 4. Special education finance formulas

\begin{tabular}{|l|l|l|}
\hline Formula & Advantages & Disadvantages \\
\hline $\begin{array}{l}\text { Weighted Pupil: Funding allocation } \\
\text { that varies based on disability, } \\
\text { placement, or student need } \\
\text { (sometimes referred to as census- } \\
\text { based). }\end{array}$ & $\begin{array}{l}\text { Ability to vary funding based on } \\
\text { need level. }\end{array}$ & $\begin{array}{l}\text { May influence severity of } \\
\text { identification rates. }\end{array}$ \\
\hline $\begin{array}{l}\text { Resource Based: Payments are } \\
\text { made for various education } \\
\text { resources such as teachers, and is } \\
\text { usually calculated based on } \\
\text { staff/student ratios. }\end{array}$ & $\begin{array}{l}\text { Ability to concentrate funding in } \\
\text { school boards serving a large } \\
\text { number of children with } \\
\text { exceptionalities. }\end{array}$ & $\begin{array}{l}\text { It may lead to resources being } \\
\text { spread too thin across boards. }\end{array}$ \\
\hline $\begin{array}{l}\text { Percentage Reimbursement: Under } \\
\text { this model, funding is based on a } \\
\text { percentage of allowable, actual } \\
\text { expenditures. }\end{array}$ & $\begin{array}{l}\text { Ability to concentrate funding in } \\
\text { school boards serving a large } \\
\text { number of children with } \\
\text { exceptionalities. }\end{array}$ & $\begin{array}{l}\text { It may lead to resources being } \\
\text { spread too thin across boards. }\end{array}$ \\
\hline $\begin{array}{l}\text { Actual Costs: Funding is based on } \\
\text { the actual cost of providing special } \\
\text { education services. }\end{array}$ & $\begin{array}{l}\text { Funding is based on real student } \\
\text { needs. }\end{array}$ & $\begin{array}{l}\text { Funding may be positively or } \\
\text { negatively impacted by the } \\
\text { estimates made. }\end{array}$ \\
\hline
\end{tabular}

On the other hand, vertical equity argues that individuals are dissimilar, and to treat everyone in a like manner is unfair. In essence, "fairness does not mean sameness." In terms of special education, it is most important to remain acutely aware of the fact that every child is sui generis, or unique in and of themselves. As such, services that are required and yield positive results for one child may not be as effective with another child, even if both are diagnosed with the same exceptionality. In the context of Nova Scotia, one cannot lose site of the fact that the urban/rural split also impacts questions of equity. Students in rural areas of the province do not have access to the same level and degree of services that those in urban areas may enjoy. As such, and not to be labour the point, but any question of funding needs to take into account and be respectful of the issue of vertical equity.

On another front, future funding arrangements in Nova Scotia need to center around the notion of interdepartmental/agency cooperation. In looking at jurisdictions such as Newfoundland and Labrador and Manitoba, this notion of cooperation is already a constituent feature of the provincial landscape. In terms of children with exceptionalities, it is important that the view that this is solely a matter under the purview of the Department of Education and Early Childhood Development be abandoned. The siloed approach does not work, and students with exceptionalities would 
benefit tremendously from a collaborative approach where working together and the pooling of resources is the norm. A natural link can and should be forged between various departments, including but not limited to Education and Early Childhood Development, Justice, and Health and Wellness. Interestingly enough, the Nova Scotia Special Education Policy notes that the "Department of Education collaborates with other government departments responsible for the well-being of children and youth to help ensure consistent and comprehensive services for students with special needs" (2008, p. 45). Unquestionably, “...better communication among the ministries delivering services would provide a more complete picture of a person's disability needs overall and should help improve service delivery" [42]. The issue of cooperation was highlighted in the 2014 Report of the Minister's Panel on Education, in which it stated that departments must work together in concert (p. 43). So, the time is ripe to usher in an era where cooperation is the norm, and not the exception.

To take the notion of cooperation a step further, it would be equally advantageous if school boards within and between provinces cooperated. There is much to be learned from one another, and healthy dialogue can only help to serve the best interests of all children in schools [42].

It might also be time to re-examine the whole notion of centralized funding that has become the norm in Canada. As such, a decentralized model where more power is vested in the hands of individual boards and schools might prove advantageous. Research has found that such arrangements can yield positive dividends [23]. At the same time, a proviso is offered in that this decentralization should not be unfettered, as accountability measures must be part of the apparatus.

In addition to vertical equity, interdepartmental/agency cooperation, and decentralized funding, Baker, Green and Ramsey [2] as well as Mitchell [25] discuss various special education finance formulas beyond the block grant funding model (see Table 4).

Although each of the above formulas have pros and cons, the weighted pupil arrangement is appealing in that it recognizes that in the area of exceptionalities, difference is the norm. By being able to allocate funding that takes into account issues such as disability, placement, and need, boards would be better equipped to provide required services. Although there exists the potential for the "bounty phenomenon" to creep in, if boards are receiving the resources that meet their divergent needs, then this likelihood is mitigated.

In examining special education funding from a purely macro-level perspective, and quite simply put, schools must be provided with the "...support and guidance to develop their capacity to identify and respond to, the learning needs of students, to utilize resources to best effect and to record and measure outcomes for students with special educational needs (National Council for Special Education, 2014, p. 3).

\section{Conclusion}

As Towle [42] points out, “....the majority of special education policies in place across the country are more than 10 years old. While some provinces are beginning the process of conducting reviews or reports assessing their special education approaches, the fact remains that many of these policies are out of step with current practices around inclusive education."

In Nova Scotia, it is time to revisit the provincial special education framework. However, as a cautionary note, Peters [38] reminds us of the adage that states that "...there are two kinds of fools: those who say this is old and therefore good and those who say this is new and therefore better." In terms of special education funding, this maxim resonates quite strongly. There are without question elements of the current system that need to be tweaked or outright replaced, but at the same time, there are features that still work remarkably well. At the same time, does something new and shiny necessarily guarantee a marked improvement? The issue for policy makers will be to ascertain what to keep and what to discard.

The preceding discussion has demonstrated that special education as a system, and the various funding models used to finance said system, are complex. While we may choose to draw comparisons among jurisdictions, and look for alternatives elsewhere, approaches to special education funding should not be judged out of the context in which they are applied (European Agency for Special Needs and Inclusive Education, 2016). Just because a particular formula has worked in another geographic locale does not necessarily mean it is easily transferable to the Nova Scotia context. Too often, policy has been "borrowed" from other jurisdictions with often less than impressive results.

Another valuable point to remember is that there is no one perfect special education funding model, as each has pros and cons. Perhaps what is required is a pluralist approach where we draw upon the best features of the competing models and concoct an amalgam. Regardless of what approach is ultimately adopted, policy makers will hopefully choose to construct a "made in Nova Scotia" formula that combines the most desirable elements from among the competing models.

As far back as 1867, there was general recognition that education was a local responsibility - a fact that was eventually enshrined in law in the British North America Act. As we fast forward to 2018, education remains a 
sacrosanct provincial/territorial responsibility. In sum, the local should not be lost in our discussions. Nova Scotia is a unique geo-political unit, and policy should reflect this unique local character.

\section{References}

[1] Alberta Education. (2004). Standards for special education. Edmonton, Canada: Author.

[2] Baker, B.D., Green, P.C., \& Ramsey, M.J. (2012). Financing education for children with special needs (pp. 97114). In J.B. Crockett, B.S. Billingsley, \& M.L. Boscardin (Eds.), Handbook of leadership and administration for special education. New York, NY: Routledge.

[3] Bezeau, L.M. (1995). Educational administration for Canadian teachers (2nd ed.). Toronto, Canada: Copp Clark.

[4] Bowlby, B., \& Reesor, L. (2017). Special education law in Canada (pp. 259-285). In D.C. Young (Ed.), Education law in Canada: A guide for teachers and administrators. Toronto, Canada: Irwin Law.

[5] British Columbia Ministry of Education. (2016). Special education services: A manual of policies, procedures, and guidelines. Vancouver, Canada: Author.

[6] Daniel, Y. (2005). The textual construction of high needs for funding special education in Ontario. Canadian Journal of Education, 28(4), 763-783.

[7] Edmunds, A.L. (2003). The inclusive classroom-Can teachers keep up? A comparison of Nova Scotia and Newfoundland \& Labrador perspectives. Exceptionality Education Canada, 13(1), 29-48.

[8] Edmunds, A., \& Edmunds, G. (2008). Special education in Canada (1st ed.). Toronto, Canada: McGraw-Hill Ryerson.

[9] Edmunds, A.L., Halsall, A., Macmillan, R.B., \& Edmunds, G.A. (2000). The impact of government funding cuts on education: Report from a teacher survey. Halifax, Canada: Nova Scotia Teachers' Union.

[10] European Agency for Special Needs and Inclusive Education. (2016). Financing of inclusive education. Odense, Denmark: Author.

[11] Froese-Germain, B., Riel, R., \& McGahey, B. (2012). Class size and student diversity: Two sides of the same coin. Retrieved from http://perspectives.ctf-fce.ca/en/article/1938/

[12] Gordon, A. (2017). Province boosts education funding to $\$ 24 \mathrm{~b}$ for next school year. Retrieved from https://www.thestar.com/amp/yourtoronto/education/2017/04 /13/province-boosts-education-funding-to-24b-for-nextschool-year.html

[13] Gouvernement du Québec. (2007). Organization of educational services for at-risk students and students with handicaps, social maladjustments or learning difficulties. Québec City, Canada: Author.

[14] Government of Newfoundland and Labrador. (n.d.). Inclusive schools. Retrieved from http://www.ed.gov.nl.ca/ edu/k12/inclusion.html.

[15] Government of Northwest Territories. (2017). NWT ministerial directive on inclusive schooling. Yellowknife, Canada: Author.

[16] Government of Saskatchewan. (n.d.). Supporting students with additional needs. Retrieved from

https://www.saskatchewan.ca/residents/education-andlearning/prek-12-education-early-learning-and-schools/ supporting-students-with-additional-needs

[17] Griffiths, D. (2013). Principals of inclusion: Practical strategies to grow inclusion in urban schools. Burlington, Canada: Word and Deed.

[18] Hutchinson, N.L. (2017). Inclusion of exceptional learners in Canadian schools: A practical handbook for teachers (5th ed.). Toronto, Canada: Pearson.

[19] Jesson, J.K., Matheson, L., \& Lacey, F.M. (2013). Doing your literature review: Traditional and systematic techniques. Thousand Oaks, CA: Sage.

[20] Jordan, A. (2007). Introduction to inclusive education. Mississauga, Canada: John Wiley \& Sons Canada.

[21] MacLeod, A., \& Emes, J. (2017). Education spending and public student enrolment in Canada. Vancouver, Canada: Fraser Institute.

[22] Manitoba Education, Citizenship and Youth. (2004). Working together: A handbook for parents of children with special needs in school. Winnipeg, Canada: Author.

[23] Meijer, C.J.W. (1999). Financing of special needs education: A seventeen-country study of the relationship between financing of special needs education and inclusion. Middelfart, Denmark: European Agency for Development in Special Needs Education.

[24] Minister's Panel on Education. (2014). Disrupting the status quo: Nova Scotians demand a better future for every student. Halifax, Canada: Province of Nova Scotia.

[25] Mitchell, D. (2010). Education that fits: Review of international trends in the education of students with special educational needs. Retrieved from https://www.educationcounts.govt.nz/publications/special_ed ucation/education-that-fits/executive-summary

[26] Murgatroyd, S., \& Couture, J-C. (2013). Rethinking equity: Creating a great school for all. Edmonton, Canada: Collaborative Media Group. 
[27] National Council for Special Education. (2014). Delivery for students with special educational needs: A better and more equitable way. Trim, County Meath, Ireland: Author.

[28] New Brunswick Department of Education and Early Childhood Development. (2013). Inclusive education. Retrieved from http://www2.gnb.ca/content/dam/gnb/ Departments/ed/pdf/K12/policies-politiques/e/322A.pdf

[29] Nova Scotia Department of Education. (2008). Special education policy. Halifax, Canada: Author.

[30] Nunavut Department of Education. (2008). Foundation for inclusive education in Nunavut schools. Iqaluit, Canada: Author.

[31] OECD. (2017). Education at a glance 2017: OECD indicators. Paris, France: OECD Publishing.

[32] OECD. (n.d.). Education spending. Retrieved from https://data.oecd.org/eduresource/education-spending.htm

[33] Ontario Ministry of Education. (2017). Special education in Ontario: Kindergarten to grade 12 policy and resource guide. Toronto, Canada: Author.

[34] Parkay, F.W., Hardcastle Stanford, B., Vaillancourt, J.P., \& Stephens, H.C. (2009). Becoming a teacher (3rd Can. ed.). Toronto, Canada: Pearson.

[35] Parrish, T.B. (1994). Fiscal issues in special education: Removing incentives for restrictive placements. Palo Alto, CA: American Institutes for Research, Center for Special Education Finance.

[36] Parrish, T.B., \& Chambers, J.G. (1996). Financing special education. Special Education for Students with Disabilities, 6(1), 121-138.

[37] People for Education. (2015). Ontario's schools: The gap between policy and reality. Retrieved from https://peopleforeducation.ca/wp-content/uploads/2017/ 10/P4E-Annual-Report-2015.pdf

[38] Peters, F. (2017). The legal and administrative framework of education in Canada (pp. 19-58). In D.C. Young (Ed.), Education law in Canada: A guide for teachers and administrators. Toronto, Canada: Irwin Law.

[39] Prince Edward Island Department of Education, Early Learning and Culture. (2015). Education handbook for school administrators. Charlottetown, Canada: Author.

[40] Ryan, J. (2006). Inclusive leadership. San Francisco, CA: Jossey-Bass.

[41] Statistics Canada. (2017). Education indicators in Canada: An international perspective. Retrieved from http://www.statcan.gc.ca/pub/81-604-x/2017001/hl-fs-eng. htm
[42] Towle, H. (2015). Disability and inclusion in Canadian education: Policy, procedure, and practice. Ottawa, Canada: Canadian Centre for Policy Alternatives.

[43] UNESCO. (1994). The Salamanca statement and framework for action on special needs education. Paris, France: Author.

[44] Weber, K., \& Bennett, S. (2004). Special education in Ontario schools (5th ed.). Palgrave, Canada: Highland Press.

[45] Winzer, M. (2008). Children with exceptionalities in Canadian classrooms (8th ed.). Toronto, Canada: Pearson.

[46] Young, D.C. (2017). Educator rights and duties (pp. 83111). In D.C. Young (Ed.), Education law in Canada: A guide for teachers and administrators. Toronto, Canada: Irwin Law.

[47] Young, D.C. (2010). The philosophy and policies of inclusion: An administrator's guide to action (pp. 53-63). In A.L. Edmunds \& R.B. Macmillan (Eds.), Leadership for inclusion: A practical guide. Rotterdam, The Netherlands: Sense Publishers.

[48] Young, J., Levin, B., \& Wallin, D. (2007). Understanding Canadian schools: An introduction to educational administration (4th ed.). Toronto, Canada: Nelson.

[49] Yukon Department of Education. (2015). Yukon education. Retrieved from http://www.education.gov.yk.ca/ pdf/schools/SSS_Manual_BYukon_Education.pdf. 